\title{
EFFECTS OF INSTITUTIONAL ENVIRONMENT AND TECHNOLOGY DEVELOPMENT ON PAYMENT CHOICE
}

\author{
Francisco J. CALLADO-MUÑOZa, Jana HROMCOVÁ ${ }^{\mathrm{b}}$, \\ Natalia UTRERO-GONZÁLEZc \\ ${ }^{a, c}$ Centro Universitario de la Defensa de Zaragoza, Academia General Militar, \\ Carretera de Huesca s/n, 50090, Zaragoza, Spain \\ ${ }^{b}$ Universitat Autònoma de Barcelona, Departament d'Economia Aplicada, \\ Edifici B, 08193, Bellaterra, Barcelona, Spain
}

Received 03 February 2014; accepted 02 May 2015

\begin{abstract}
The purpose of this paper is to analyze the combination of institutional factors and technology advances as determinants for the choice of payment instruments. The theoretical set up suggests that countries that enter into a new institutional environment adopt the attitudes of the accepting group towards the payment choices as a consequence of institutional pressure and technology development. We apply the results of the model to the European Union enlargement process of 2004. Our findings confirm the relevance of both institutional environment and technology development in retail payment choice decisions particular to Central and Eastern European Countries.
\end{abstract}

Keywords: technology, institutions, European integration, payment.

JEL Classification: E42, E51, G21, O52.

\section{Introduction}

Continuous evolution of information technologies has led to a significant transformation of the payment industry (Evans, Schmalensse 2009). A well-designed payment infrastructure is important for the proper functioning of markets and helps in eliminating frictions in trade. Reliable and safe payment mechanisms for the transfer of funds are the condition sine qua non for the majority of economic interactions (ECB 2010). The degree of technology development is a key element in consumer decision to move from cash or paper to electronic means of payment as well. Previous papers (Ireland 1994b; Marquis, Reffett 1994; English 1999; Hromcová 2008) relate the choice of payment instruments to the technological progress. Empirically, Humphrey et al. (1996) find that the availability

Corresponding author Francisco J. Callado-Muñoz

E-mail:fcallado@unizar.es 
of new payment methods, the existence of a corresponding technology at the disposal of consumers, explains part of the differences found in payment use in a group of developed countries. Markose and Loke (2003) show that the decrease in the use of cash and its substitution by cards is affected by the availability of payment terminals at the point of sale. Hayashi and Klee (2003) and Anguelov et al. (2004) show that general technology adoption by consumers is positively related to the use of electronic payments. Similarly, Snellman and Virén (2009), Ferrari et al. (2010) and Yang and Ching (2013) have offered evidence on the impact that automatic teller machine (ATM) networks have in consumers' decisions. Further, Humphrey et al. (2006) and Hasan et al. (2012) found that the development in the use of electronic retail payment instruments is related to notable improvements in banking performance. In addition, Hasan et al. (2013) show that the migration to electronic retail payments spurs overall economic development. Therefore, countries might be interested in technology adoption as part of their economic progress.

Development of new payment technologies does not imply the elimination of traditional methods. Consumers ultimately determine which of these instruments they actually use. Once consumers and merchants get comfortable with a particular technology, they need a compelling reason to switch to another one. First of all, for a new method of payment to be successful, it must attract substantial number of users, offer significant cost savings or add convenience relative to the existing payment instruments. Second, whatever its cost or convenience, a payment method must be trustworthy and secure, otherwise people will not use it (Litan, Baily 2009). The existence of a sound and reliable institutional environment could clearly help consumers' perception of security and convenience. National and supranational regulations can provide additional incentives to users and thereby accelerate the acceptance of a particular payment instrument. La Porta et al. (1997) show the role of the institutional environment and national regulations in shaping financial market design that could also influence the retail payment choice development. In fact, the work on the minimal institutional requirements imposed on payment methods, by the Committee on Payment and Settlement Systems, is considered to serve as a guideline (BIS 2005). To the best of our knowledge the combination of institutional factors and technology advances has not been analyzed together as possible determinants of payment choice.

This paper tries to fill this gap by focusing on institutional and technological characteristics both from a theoretical and empirical point of view. In particular, the paper analyzes how the process of entering an economic and monetary union could shape the evolution of consumers' payments in newly acceded countries. It considers the role of new institutions together with the technology advances derived from that integration. The conclusions of the theoretical analysis are then tested on the particular case of European Union (EU) enlargement to Central and Eastern European countries (CEECs) ${ }^{1}$. This context is particularly challenging because the enlargement process has proven to be successful in providing institutions' building and structural transformation for CEECs (Dabrowski, Radziwill 2007). On May 1st, 2004 the EU welcomed ten more countries as a part of its largest enlargement ever. The accession of the new members increased the EU population by nearly $20 \%$ but

\footnotetext{
${ }^{1}$ Note that the OECD definition of CEECs slightly differs from the group of countries used here. We replace Albania and Croatia by Cyprus and Malta, but the core of the members is unchanged.
} 
the EU's total gross domestic product (GDP) increased just by $4 \%$ (Hildebrandt 2002$)^{2}$. The CEECs integration negotiations required the implementation of the acquis communautaire, the set of laws that underpin the common market, by EU accession. In other words, CEECs financial sectors were expected to be transformed to such an extent that the supervisory and legal framework reached more or less EU standards in order to grant membership. Moreover, EU financial sector has also been experiencing a profound change -deregulation, disintermediation, technological change and single currency-representing, in fact a moving target to the CEECs authorities (Stirbu 2004).

In light of the above discussion, the first objective of the paper is to develop a theoretical model. We want to describe the effects that, in terms of the existence of technology advances, the accession to an economic and monetary union can have on household payment choice. We assume that consumers have two ways of acquiring consumption goods, cash and electronic payments. Technology is crucial for the development of the payment context. We introduce payment characteristics from Hromcová (2008) into the model of Ireland (1994a). In a resulting setup, knowledge improvement leads to more sophisticated payment environment and cheaper electronic transactions. In the process of accession, the less developed economy (accessing country) gradually adapts to the payment standards of the more developed economy (accepting country). As a consequence, agents' payment choice approaches the one of the consumers in the more developed country. The second objective of the paper is to estimate the results of the model. For that, we use data on EU payment choice for the candidate countries to access EU in 2004. Furthermore, data availability allows us to study the joint effect of institutional environment and technology development on payment decisions.

The rest of the paper is organized as follows. Section 1 explains the institutional transformation to EU integration. Section 2 describes the theoretical model. Section 3 presents the empirical analysis. Finally, we conclude.

\section{Institutional transition towards EU accession}

In May 2004, ten new states (Czech Republic, Estonia, Cyprus, Hungary, Latvia, Lithuania, Malta, Poland, Slovenia and Slovakia) become members of the EU. For eight of these countries, membership is the culmination of a decade-long transition from central planning to market economies. The fall of Communism in Europe creates an opportunity to end the historical East-West division in Europe associated with the Cold War. The European Economic Community (European Union from 1993) starts to sign comprehensive Europe Association Agreements with CEECs in 1991. The European integration is the strategic direction from day one of transition (Dabrowski, Radziwill 2007). Three different stages in the EU integration process are defined: associate, applicant and negotiating. The strategy of linking reforms to integration stage (see Fig. 1) allows EU to monitor effectively the comprehensive process of institutional quality improvements and intensify structural reforms to satisfy all the conditions for membership.

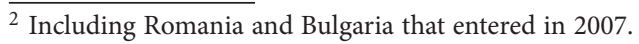




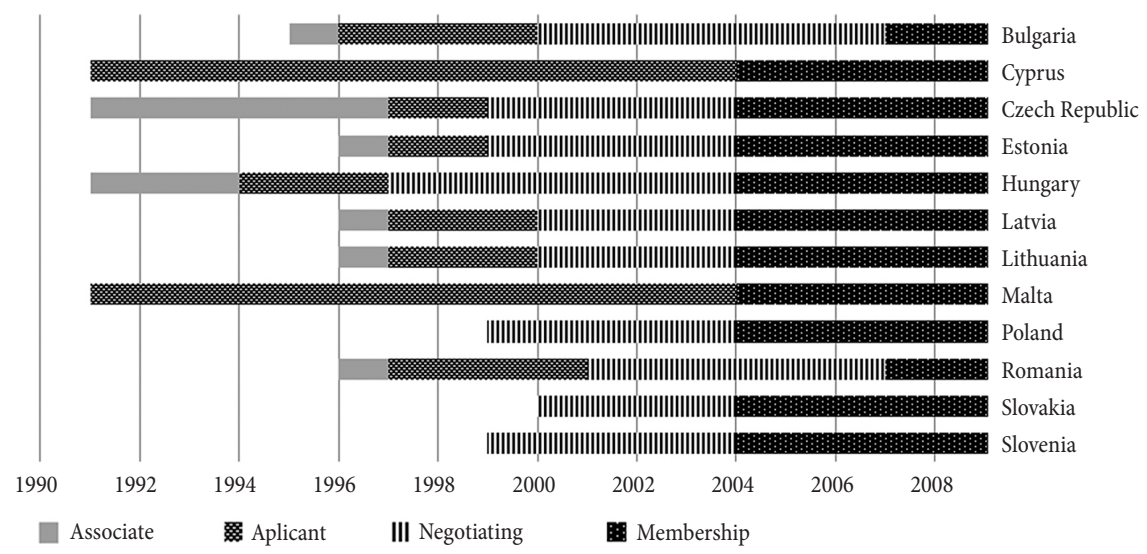

Fig. 1. Timetable of EU integration process of Central and Eastern European Countries (CEECs)

Specifically, EU membership means embracing the Union's political, economic and social values such as democracy, rule of law, competitive and open markets, and social cohesion. Second, it implies structural reforms in economic sectors. In the financial area the requirements are to fully liberalize the capital movements to adopt the EU regulatory norms and prudential rules. This includes, for example, the implementation of central bank independence, legislation on the free movement of capital and freedom of payments, the provision of banking, securities trade and investment services, collateral rules, and legislation aiming at an internal market for financial services. For instance, the Financial Services Action Plan (ECB 2002) is the driving force and the key instrument for bulging an efficient financial system and financial convergence with the EU (Stirbu 2004). The effort made by CEECs to satisfy membership conditions in this respect has been immense. Financial system reforms started in the early 1990s to transform the public banking sector inherited from the communist system. However, the banking crises that were suffered during this transition process slowed down the reforms (Tang et al. 2000). We find CEECs at the initial stage of evolution and growth in 1999.

Before accession, the financial systems of the CEECs had three main characteristics. First, there was a strong dominance of the banking sector and capital markets were not usually used as a source of finance. Second, the level of financial intermediation remained relatively low, even in those countries with the most developed financial markets, Czech Republic, Hungary and Poland (ECB 2002). The relation of banking assets to the economies' GDP amounted to about one-quarter of the corresponding figure for the euro area in 2001 (Caviglia et al. 2002). Further, in the liabilities side, deposits represented one third of those in the euro area as a share of GDP (Caviglia et al. 2002). Finally there was a strong presence of foreign ownership in the domestic banking sector (Caviglia et al. 2002; Stirbu 2004). Foreign investors were said to help bringing capital and know-how, strengthening competition and contributing to the successful restructuring process (Thimann 2002). However, in addition to the low financial intermediation stated above, many of the foreign-owned banks used to move key activities to the headquarters, so that subsidiaries in the acces- 

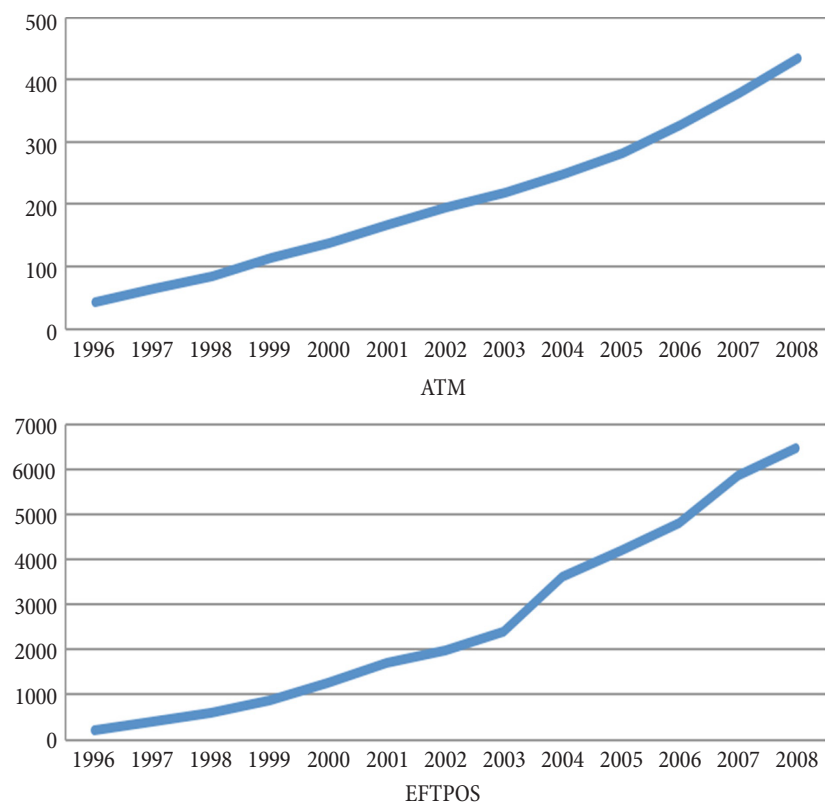

Fig. 2. ATM and EFTPOS evolution (number of facilities per 1 million inhabitants)

sion countries lose some of their important functions (Thimann 2002). In these settings, the EU accession is viewed as an important structural change for the banking sector by the CEECs central banks (Thimann 2002). Unsurprisingly, there is evidence of an increase in competition in the banking system due mainly to the process of European Integration (Andrieş, Capraru 2012).

With respect to the payment methods, cash was most widely used. The average percentage of cash in circulation with respect to M1 was more than three times the one for the EU in 2003 (Callado, Utrero 2004). Moreover, the use of payment cards was increasing along the integration period (applicant and negotiating status) together with the number of ATM and electronic funds transfer at the point of sale (EFTPOS) terminals. The rise of ATM and EFTPOS continued at a faster pace when membership occurred, especially in the case of the latter (see Fig. 2) ${ }^{3}$. All together, this evidence suggests a positive and continuous development of payment methods along the integration period and a relevant effect of EU accession in payment evolution.

\section{Theoretical model}

We consider two economies that differ in the initial level of development. At the beginning they are two separated countries and can have different monetary policies. With the accession moment approaching, their monetary policies must converge and at the moment of

\footnotetext{
${ }^{3}$ Average annual increase of ATM and EFTPOS during 2004-2009 compared with 1996-2003 was 67\% and 145\% higher, respectively.
} 
accession a common monetary policy applies in both economies. After the unification takes place, the accessing country gradually adopts the payment technology of the more developed one. They both maintain their own structure and other variables unchanged. Technology level is crucial for the payment environment. The higher the technology achieved, the cheaper the non-cash payments. As a measure of technology, we use the level of capital in the sense of the learning-by-doing model (Barro, Sala-i-Martin 1995). Because the learning-by-doing model can be reduced to an AK model, for simplicity of our theoretical setup, we assume that the production function has the linear form. However, we keep reminding the reader that the level of capital is the measure of achieved knowledge, and higher knowledge leads to higher technological level.

In the description of the model we follow closely Ireland (1994a) and Hromcová (2008). The behavior of households in both countries is analogous. Therefore, we present the model for the economy that begins with lower level of technology and at the end of the section we generalize the model for the other country.

\subsection{Accessing country}

\subsubsection{Household problem}

The economy consists of a large number of infinitely lived households. All households have identical preferences, production and trade opportunities. Households inhabit the following environment: they face continuum of spatially separated markets, which are indexed by $j \in[0,1]$. All households live in market 0 , and the index $j$ indicates the distance from home. In each market $j$ a distinct perishable good is produced and sold in every period. Goods are thus indexed by $j$, which corresponds to the market of both production and trade. The representative household has the preferences given by:

$$
\sum_{t=0}^{\infty} \beta^{t} \int_{0}^{1} u\left[c_{t}(j)\right] d j,
$$

where $\beta$ is the discount factor, $c_{t}(j)$ is defined as the consumption at period $t$ of the good produced in market $j, u(\cdot)$ is strictly increasing, strictly concave and twice continuously differentiable, with $\lim _{t \rightarrow \infty} u^{\prime}\left[c_{t}(j)\right]=\infty$.

The production and trade is like in Lucas and Stokey (1983). Each household is composed of a worker-shopper pair. Prior to any trading, central bank fixes the level of the gross nominal interest rate $R_{t+1}$ between periods $t$ and $t+1$. We will assume that $R_{t+1}>1$. Agents enter the period $t$ with certain amount of monetary balances $Z_{t}$ and the debt $B_{t}$, carried over from the previous period, and the capital stock $k_{t}$ that represents the technology level achieved. A representative worker decides to produce on any of the markets $j$ via the net production function:

$$
y_{t}=A k_{t}
$$

where $A$ is the net productivity of capital ${ }^{4}$.

\footnotetext{
${ }^{4}$ Thanks to the AK technology, we can write the net production function as $y_{t}=\left(A^{\prime}+1-\delta\right) k_{t}$. It corresponds to the one defined in the equation (2), where $A^{\prime}$ is the marginal productivity and $\delta$ is the depreciation of capital.
} 
First, the goods market opens and consumption takes place. Worker stays at the market $j$ during the whole period. Shopper visits various markets to acquire consumption goods carrying all the monetary balances of the household. Two ways of acquiring consumption goods are allowed: using money or electronic payments. All goods purchased with money will be referred to as cash goods. Goods purchased via electronic payments will be referred to as electronic goods. Nominal monetary balances $Z_{t}$ can be used to buy goods in some of the markets indexed by $j$. Cash purchases are subject to the liquidity constraint:

$$
\int_{0}^{1}\left[1-\xi_{t}(j)\right] c_{t}(j) d j \leq \frac{Z_{t}}{p_{t}},
$$

where $\xi_{t}(j)=0$ if a good is purchased on market $j$ with cash, or $\xi_{t}(j)=1$ if a good is purchased on market $j$ via an electronic payment and $p_{t}$ is the price level.

As said above, agents can use an electronic payment to pay for the consumption. The financial intermediary enables electronic payments at a cost $\gamma_{t}(j)$ that is given for each market $j$ and period $t$. The part of output that is not consumed is devoted to the investment into capital. After the goods market closes, the monetary holdings of agents are augmented by a lump sum transfer $X_{t}$ from the central bank. The amount $X_{t}$ is endogenously determined in the system according to the given nominal interest rate, so that the money demand is totally satisfied. As the next step, the securities market opens. During the securities trading session households choose their currency holdings $Z_{t+1}$. They also purchase (or issue) one-period nominally denominated pure discount bonds paying $B_{t+1}$ units of money at period $t+1$ while they cost $\frac{B_{t+1}}{R_{t+1}}$ units of money at period $t$. Bonds are in zero net supply. The budget constraint agents are facing can be written:

$$
\int_{0}^{1}\left[c_{t}(j)+\xi_{t}(j) \gamma_{t}(j)\right] d j+k_{t+1}+\frac{Z_{t+1}}{p_{t}}+\frac{B_{t+1}}{R_{t+1} p_{t}} \leq A k_{t}+\frac{Z_{t}}{p_{t}}+\frac{B_{t}}{p_{t}}+\frac{X_{t}}{p_{t}} .
$$

\subsubsection{Financial intermediation}

We assume that the intermediation cost must be paid by the buyer, as motivated in Ireland (1994b). To be able to purchase without cash, some resources must be devoted to making the non-cash payment itself available such as checking the identity of the buyer or her ability to pay. When the shopper is far away from home (market zero) the communication becomes more difficult, and therefore we assume that the payment to the intermediary increases with $j$. The process of learning-by-doing grants a potential for the development of new technologies. It also leads to an increase in income per worker and higher consumption. Higher purchase means that checking the ability of the buyer to pay is more relevant. The development and diffusion of new technologies drives down the processing costs.

The real payment made to the intermediary is characterized by a function that fulfills properties found in some empirical studies, as described in Hromcová (2008): the intermediation cost is lower in richer countries, the cost of intermediated payment diminishes over time, and the cost elasticity is close to zero, i.e. the cost is proportional to consumption purchase. We specify the intermediation cost function as a composition of three parts: 


$$
\gamma_{t}(\cdot)=\gamma^{\text {location }}(j) \gamma^{\text {technology }}\left(k_{t}\right) \gamma^{\text {consumption }}\left[c_{t}(j)\right] .
$$

The time independent part of the payment, $\gamma^{\text {location }}(j)$ is strictly increasing with the distance from home, strictly convex, twice continuously differentiable, and similarly to Ireland $(1994 \mathrm{a})^{5}$ we assume:

$$
\gamma^{\text {location }}(j)=0 \text { and } \lim _{t \rightarrow \infty} \gamma^{\text {location }}(j)=\infty \text {. }
$$

The function $\gamma^{\text {technology }}\left(k_{t}\right)$ is strictly decreasing, strictly convex, twice continuously differentiable and $\lim _{t \rightarrow \infty} \gamma^{\text {technology }}\left(k_{t}\right)=0$. The time dependent part of the intermediation cost, $\gamma^{\text {technology }}\left(k_{t}\right)$, embodies the effect of new technologies on the cost. It includes the state of the technology frontier as well as the net of electronic infrastructures to perform the electronic payments. This cost decreases as the level of technology develops. The more capital is accumulated, the more knowledge is available, better technologies can be developed and cheaper intermediation services can be offered. The other time dependent part of the intermediation cost, $\gamma^{\text {consumption }}\left[c_{t}(j)\right]$, is increasing, linear in consumption and $\gamma^{\text {consumption }}(0)=0$.

We thus concentrate directly on the effect of new technologies on the intermediation cost. However, the scale economies are also present, because higher stock of knowledge is associated with higher volume of transactions.

\subsubsection{Payment choice}

Consider a given level of $k_{t}$. The cost of cash goods is the same in all markets and it corresponds to the nominal interest rate. The cost of electronic goods increases with the distance from home, taking into account the assumption on the time independent part of the intermediation cost $\gamma^{\text {location }}(\cdot)$, equation (6). Whenever $R_{t+1}>1$, there will exist at each time $t$ an interval of markets where the intermediation cost for electronic purchases is lower than the nominal interest rate, and an interval where it is higher. Therefore, there will exist a market with cutoff index $s_{t} \in(0,1)$, such that in all markets with indexes $j<s_{t}$ consumers will use electronic payments and in all markets with indexes $j \geq s_{t}$ consumers will use cash to acquire consumption goods. Thus households will choose cash goods in markets far away from home (market 0 ) and electronic goods in markets close to home ${ }^{6}$.

In the cutoff market consumers are indifferent between using cash or electronic payments. We arbitrarily assume that cash will be used at the cutoff market. In our specification the level of new knowledge increases over time. Changes in $k_{t}$ affect the payment to intermediary via $\gamma^{\text {technology }}\left(k_{t}\right)$. Therefore, technology development and interest rate are

\footnotetext{
5 The combination of the term referring to location and technology reflects the convergence of, for example, local and long distance phone call prices in recent years. Location term in the cost function guarantees the spatial separation of markets. It allows expressing exchange opportunities in communication. An equivalent modelling approach could be based on a characteristic reflecting agents' openness or willingness to accept and use electronic payments. Such an alternative specification would not alter the conclusions of the model.

${ }^{6}$ What is important here is that the consumer chooses the point of division on the continuum of markets. One could construct the model in a way that cash is employed in markets close to home and electronic payments in markets far away from home adapting the approach of Gillman (1993), for example. Such assumption would not change the conclusions of our model, however.
} 
factors that affect the cutoff index $s_{t}$ : an increase in the level of technology, $k_{t+1}>k_{t}$, implies lower intermediation cost and therefore, electronic payments will be employed in higher fraction of the markets, $s_{t+1}>s_{t}$; an increase in the nominal interest rate, $R_{t+1}>R_{t}$, increases the opportunity cost of holding money, and cash will be employed in lower fraction of the markets, $s_{t+1}>s_{t}$.

Define

$$
c_{t}(j)=\left\{\begin{array}{lll}
c_{t}^{0}(j), & \text { when } & \zeta_{t}(j)=0, \\
c_{t}^{1}(j), & \text { when } & \zeta_{t}(j)=1 .
\end{array}\right.
$$

The functions $c_{t}^{0}(j)$ and $c_{t}^{1}(j)$ characterize the cash and electronic consumption per market $j$, respectively.

\subsubsection{Equilibrium}

Definition: Given the set of initial conditions $k_{1}, Z_{1}, B_{1}, p_{1}$ and the sequence of nominal interest rates $\left\{R_{t+1}\right\}_{t=0}^{\infty}$, the equilibrium consists of sequences $\left\{c_{t}^{0}(j), c_{t}^{1}(j), k_{t+1}, Z_{t+1}, B_{t+1}, s_{t}, X_{t}, p_{t+1},\right\}_{t=1}^{\infty}$ such that

(a) a representative household is maximizing the discounted utility (1) subject to the budget constraint (4) and the cash-in-advance constraint (3), choosing the sequences $\left\{c_{t}^{0}(j), c_{t}^{1}(j), k_{t+1}, Z_{t+1}, B_{t+1}, s_{t}\right\}_{t=1}^{\infty}$,

(b) markets for goods, money and bonds clear in every period ${ }^{7}$,

$$
\begin{gathered}
A k_{t}=\int_{s_{t}}^{1} c_{t}^{0}(j) d j+\int_{0}^{s_{t}} c_{t}^{1}(j) d j+\int_{0}^{s_{t}} \gamma_{t}(j) d j+k_{t+1} \\
Z_{t+1}=Z_{t}+X_{t} \\
B_{t+1}=0 .
\end{gathered}
$$

Let $\lambda_{t}$ and $\eta_{t}$ be the non-negative Lagrange multipliers associated with the budget constraint (4) and the cash-in-advance constraints (3), respectively. The equations that characterize the equilibrium are the above mentioned market clearing conditions (7), (8), (9) and the first order conditions on consumption, capital, nominal balances, nominal bonds and cutoff index, respectively,

$$
\begin{gathered}
u^{\prime}\left[c_{t}^{0}(j)\right]=\lambda_{t}+\eta_{t} ; \\
u^{\prime}\left[c_{t}^{1}(j)\right]=\lambda_{t} ; \\
\lambda_{t}=\beta \lambda_{t+1} A ;
\end{gathered}
$$

\footnotetext{
${ }^{7}$ Notice that the conditions on the electronic payments correspond pretty closely with the credit card operations. When paying with electronic payments, consumer can keep the interest rate payment up to the point when money is transferred away from his account. In the model this happens at the end of each period. Thus the debit card payments will be quicker in reality, and the delayed credit card payments will be slower.
} 


$$
\begin{gathered}
\frac{\lambda_{t}}{p_{t}}=\beta \frac{\lambda_{t+1}+\eta_{t+1}}{p_{t+1}} ; \\
\frac{\lambda_{t}}{p_{t}}=\beta R_{t+1} \frac{\lambda_{t+1}}{p_{t+1}} ; \\
u\left[c_{t}^{0}\left(s_{t}\right)\right]-u\left[c_{t}^{1}\left(s_{t}\right)\right]=-\lambda_{t}\left[c_{t}^{1}\left(s_{t}\right)+\gamma_{t}\left(s_{t}\right)\right]+\left(\lambda_{t}+\eta_{t}\right) c_{t}^{0}\left(s_{t}\right) .
\end{gathered}
$$

Using (10), (11), (13) and (14), we can rewrite the first order conditions on both consumptions as follows:

$$
\begin{gathered}
u^{\prime}\left[c_{t}^{0}(j)\right]=R_{t} \lambda_{t} ; \\
u^{\prime}\left[c_{t}^{1}(j)\right]=\lambda_{t} .
\end{gathered}
$$

From the first order condition (15) we obtain the payment to the intermediary at the cutoff market:

$$
\gamma_{t}\left[s\left(R_{t}, k_{t}\right)\right]=\frac{1}{\lambda_{t}}\left\{u\left[c^{1}\left(\lambda_{t}\right)\right]-u\left[c^{0}\left(R_{t}, \lambda_{t}\right)\right]\right\}+R_{t} c^{0}\left(R_{t}, \lambda_{t}\right)-c^{1}\left(\lambda_{t}\right)
$$

Taking into account the expressions (16), (17) and (5), the equilibrium on the goods market (7) can be rewritten as:

$$
A k_{t}=\int_{s\left(R_{t}, k_{t}\right)}^{1} c^{0}\left(R_{t}, \lambda_{t}\right) d j+\int_{0}^{s\left(R_{t}, k_{t}\right)} c^{1}\left(\lambda_{t}\right) d j+\int_{0}^{s\left(R_{t}, k_{t}\right)} \gamma_{t}(j) d j+k_{t+1} .
$$

The current period output is spent among cash consumption, electronic consumption, payment to the intermediary and investment. The real monetary balances, $m_{t}=\frac{Z_{t}}{p_{t}}$, which
equal the amount of cash consumption purchased in all markets, are:

$$
m_{t}=\left[1-s\left(R_{t}, k_{t}\right)\right] c^{0}\left(R_{t}, \lambda_{t}\right)
$$

The consumption via financial intermediaries, which equal the amount of electronic consumption purchased in all markets, is:

$$
e_{t}=s\left(R_{t}, k_{t}\right) c^{1}\left(\lambda_{t}\right)
$$

Thus the ratio of cash to electronic payments depends on the specification of the intermediation function, the utility and the monetary policy in the previous period.

In order to see the behavior of the ratio of cash to electronic payments, we set up a parametric example with the constant elasticity of substitution (CES) utility function:

$$
u\left(c_{t}\right)= \begin{cases}\ln c_{t} & \text { for } \quad \theta=1, \quad \text { and } \\ \frac{c_{t}^{1-\theta}-1}{1-\theta} & \text { for } \quad \theta \neq 1\end{cases}
$$

where $\theta>0$ is the inverse of the elasticity of inter-temporal substitution, and the following proportional intermediation cost:

$$
\gamma_{t}(j)=\frac{j}{1-j} \gamma^{\text {technology }}\left(k_{t}\right) c^{1}\left(\lambda_{t}\right)
$$


We can then write the cutoff index combining (23) and (18) in the following form:

$$
s\left(R_{t}, k_{t}\right)=\frac{\phi\left(R_{t}\right)}{\gamma^{\text {technology }}\left(k_{t}\right)+\phi\left(R_{t}\right)},
$$

where

$$
\phi\left(R_{t}\right)= \begin{cases}\ln R_{t} & \text { for } \theta=1, \\ \frac{\theta}{1-\theta}\left(1-\frac{1}{R_{t} \frac{1-\theta}{\theta}}\right) & \text { for } \theta \neq 1 .\end{cases}
$$

The cutoff index describes the proportion of markets in which agents employ services of the intermediary. From (12) we can get the evolution of the marginal utility of consumption. We can see that its growth rate is constant over time. The ratio of cash to electronic consumptions can be expressed as

$$
\frac{m_{t}}{e_{t}}=\frac{\gamma^{\text {technology }}\left(k_{t}\right)}{\phi\left(R_{t}\right) R_{t}^{\frac{1}{\theta}}} .
$$

The technology level and the monetary policy affect the composition of the payment methods as follows (recall that we assumed that capital affects negatively the intermediation cost):

$$
\frac{d\left(m_{t} / e_{t}\right)}{d k_{t}}<0 \text { and } \frac{d\left(m_{t} / e_{t}\right)}{d R_{t}}<0 .
$$

For this parametric example, it can be shown that in the long run, the output, capital and electronic consumption all grow at a rate $(\beta A)^{\frac{1}{\theta}}$. The proof is provided in Appendix 1.

Notice also that the cutoff index $s\left(R_{t}, k_{t}\right)$ converges to 1 as $k_{t} \rightarrow \infty$ independently of the level of the interest rate, see equation (24). Thus the decreasing trend of the ratio of cash to electronic payments will be determined by the growth of technology.

\subsection{Accepting country}

The specification of the accessing and accepting economy is the same. When writing the version of the model for the accepting country we use the analogous notation. We substitute lower-case letters for capital letters and capital letters for blackboard bold ones, i.e. the level of technology in the accepting country will be denoted as $K_{t}$, the nominal interest factor between $t$ and $t+1$ as $\mathbf{R}_{t+1}$.

\subsection{Accessing economy before and after}

Both economies know both initial conditions and when the accession takes place, i.e. $T_{\text {access }}$ is given. They can solve their respective maximization problem as all information is available to everyone. After the accession, the accessing economy is adopting the 
payment technology of the accepting country ${ }^{8}$. We define $k_{t}^{\text {access }}$ as the level of technology that determines the intermediation cost at each market after accession. Given that the accessing country's payment technology converges to the accepting one, the gap between the payment technologies of both countries will diminish over time. The evolution of $k_{t}^{\text {access }}$ will reflect the payment technology differences and will be a function of the levels of payment technologies in both groups of countries $k_{t}^{\text {access }}=\Omega\left(k_{t-1}^{\text {access }}, K_{t}\right)$, where $k_{t} \leq k_{t}^{\text {access }}<K_{t}, \quad k_{T_{\text {access }}}^{\text {access }}=k_{T_{\text {access }}}, \lim _{t \rightarrow \infty} k_{t}^{\text {access }}=K_{t}$ and $k_{t}$ denotes the level of capital in an economy that evolves independently of the accepting country because it does (did) not access, $k_{t}^{\text {access }}$ accounts for the payment technology (capital) in the country where the accession actually happened, and $K_{t}$ is the level of capital in the accepting country ${ }^{9}$.

The intermediation cost function would be slightly modified and the ratio between cash and electronic consumptions after the accession, equation (26), depends on the payment technologies of both groups of countries and the common monetary policy, $R_{t}=\mathbf{R}_{t}$. That implies that for given levels of payment technologies and a given monetary policy, any decrease in the real balances will have to be accompanied by an increase in the electronic goods. It also implies that the accession, that means higher level of payment technology, $k_{t}^{\text {access }}>k_{t}$, induces a drop in the ratio of cash to electronic payments, as implied by (27).

\section{Empirical analysis}

According to equation (26) and the argument at the end of section 2.3, the use of alternative means of payment in the accessing countries is a function of the monetary policy and the technology level in the accessing and accepting countries. We interpret $k_{t}\left(K_{t}\right)$ as the level of technology achieved and the set of infrastructures developed to make payments. In order to empirically estimate this relationship, we take logs. Therefore, the baseline specification to estimate is:

$$
\ln \left(m_{i t} / e_{i t}\right)=\alpha_{0}+\alpha_{1}\left(R_{i t}-1\right)+\alpha_{2} \ln \left(k_{i t} / K_{t}\right)+\varepsilon_{i t},
$$

where $i$ is accessing country and $t$ is time. Variables $m / e, R-1, k / K$ account for cash to electronic operations (dependent variable), nominal interest rate, and the ratio of payment technology level in the accessing countries to the payment technology level in the accepting countries (thus no index $i$ ), respectively. The error term $\varepsilon_{i t}$ is assumed to be normally distributed with zero mean and variance $\sigma^{2}, \varepsilon_{i t} \sim \mathrm{N}\left(0, \sigma^{2}\right)$. The estimation takes into account the possible existence of non-observable heterogeneity. From an econometric point of view, the estimation of the coefficients, $\alpha_{0}, \alpha_{1}$ and $\alpha_{2}$ should take into account the structure of the components of the error term $\varepsilon_{i t}$, that is, the specific effects can be treated as fixed or random. If the effects are independent of the explanatory variables they form part of the error term, which in this case will be a compound term. When there is no correlation, we use the random effects since it is the most efficient alternative (Arellano, Bover 1990). Otherwise, the fixed effect estimator is used. Hausman test is used to determine whether the effects are fixed or random.

\footnotetext{
${ }^{8}$ Better payment technology of accepting countries is gradually transferred towards the accessing country through the process of spillovers. Technology adoption is not costly for any party.

${ }^{9}$ An example of a convergence equation could be found in Lucas (2009).
} 


\subsection{Data}

We use panel data from the EU Eastern enlargement process (2004-2007) where Cyprus, Czech Republic, Estonia, Hungary, Latvia, Lithuania, Malta, Poland, Slovakia and Slovenia joined the EU in 2004 and Bulgaria and Romania were proposed for a later acceptance ${ }^{10}$. Membership is the culmination of the integration process that starts back in 1991 for many of the CEECs. However, due to payment statistics availability the period analyzed is 1996-2009. Data on EU-15 and European Monetary Union (EMU) countries are also used for comparison purposes ${ }^{11}$. Data sources are Eurostat and European Central Bank. To eliminate size and currency effect, all variables are expressed in euros and scaled by population $^{12}$. We use data on cash and cards to account for the ratio of cash and non-cash operations (dependent variable). Short term (3-months) interest rate accounts for monetary policy as in Rinaldi (2001), among others.

The model suggests that the institutional environment influences payment methods' decisions. As explained above, the integration process is a continuous process that has different phases. First, an associate agreement is signed. Second, there is the applicant period. Third negotiations to accession start and finally accession is approved. In each phase, countries are supposed to implement reforms to approach EU institutional arrangements. Accordingly, integration variable is defined to capture the different country continuous evolution to become EU member, presenting an increasing relationship to EU accession. In particular, integration variable has the lowest values in early stages of integration process (associate) and the largest value when membership is granted.

The level of payment technology is proxied by two alternative variables widely used in the retail payment methods literature (Humphrey 2010): per capita ATM and per capita EFTPOS. The model suggests that the technology level in both accessing and accepting countries influences the payment choice in the accessing group. The ratio of ATM per capita (EFTPOS per capita) in the accessing economy to the average ATM per capita (EFTPOS per capita) in the accepting countries measures the payment technology convergence. This ratio approaches unity when the accessing countries technology level moves towards the technology development of the accepting group. The benchmark case is the comparison between the accessing countries and the EU-15. But since there is individual information on EMU countries, which have done additional efforts to homogenize payments instruments in the single currency and the objective of some of the CEECs is to adopt EMU, we consider interesting the comparison between accessing and EMU countries as well.

Since a positive relationship between economic development and electronic payment methods is evidenced in previous studies (Humphrey 2004), we introduce economic level, proxied by GDP per worker, to control for development and economic stability. Table 1 collects the definitions of the main variables and presents some descriptive statistics.

\footnotetext{
10 The panel is unbalanced.

${ }^{11}$ EU-15 are Germany, France, Belgium, Netherlands, Luxemburg, Italy, Great Britain, Ireland, Denmark, Greece, Portugal, Spain, Austria, Finland and Sweden (in membership order). Great Britain, Denmark and Sweden are not part of the EMU.

12 All variables are expressed in logs.
} 
Table 1. Definitions of variables and descriptive statistics

\begin{tabular}{lcc}
\hline \multicolumn{1}{c}{ Variable } & Accessing countries & Accepting countries \\
\hline Pccurrency & 617.03385 & 1249.556 \\
(per capita currency in circulation) & $(679.3817)$ & $(286.4857)$ \\
\hline Pccardop & 13.9415 & 52.5298 \\
(per capita card operations) & $(20.2578)$ & $(4.5398)$ \\
\hline Irate & 9.0676 & 3.0125 \\
(money market interest rate) & $(14.7708)$ & $(0.5011)$ \\
\hline Pceftpos & 0.0063 & 0.0132 \\
(per capita point of sale terminals) & $(0.0068)$ & $(0.0037)$ \\
\hline Pcatm & 0.0003 & 0.0007 \\
(per capita atm terminals) & $(0.0002)$ & $(0.0001)$ \\
\hline Pwgdp & 17758.85 & 56978.71 \\
(per worker gdp) & $(10457.44)$ & $(2571.081)$ \\
\hline
\end{tabular}

Note: Mean and standard deviation (in brackets) are reported.

Source: Own calculations. Country level data from ECB (2013) and Eurostat (2013).

The two columns show the mean and the standard deviation for all accessing countries and for the accepting countries (EU-15), respectively. Some interesting differences arise between both sets of countries and all differences are statistically significant. First, per capita currency in circulation in the accepting countries nearly doubles that of the accessing ones. This preliminary relationship is in line with previous evidence (Drehmann et al. 2002). Observing the electronic payments, accepting countries present nearly four times the operations processed in their accessing counterparts. Accepting countries present also higher per capita EFTPOS and ATM, suggesting that the payment technology is more widespread and developed than in the accessing countries. We have analyzed the correlation of the main variables. Some pairwise correlations are very high (5 out of 21 are greater than $60 \%$ ), especially ATM and EFTPOS present a correlation of $83 \%$. To avoid multicollinearity problems, we do not include both variables together. Data on country differences is available in Appendix 2 (Table A.1).

\subsection{Results}

Results are presented in Table 2. The first two columns refer to the benchmark comparison to EU-15. Columns 3 and 4 compare the accessing countries to EMU ones. Finally, the last two columns present the analysis with alternative variable definitions. Hausman test is presented at the end of the table. When the test rejects the correlation of the effects, the random effect estimator is used.

We introduce ATM and EFTPOS variables one at a time. Independently of the comparison group or the proxies used, ATM and EFTPOS, the technology level exhibits a negative and significant coefficient. This indicates that the larger the technology expansion to catch up with the accepting group, the lesser the relative use of cash, as suggested by the results of the model. The effect of ATM and EFTPOS on cash use has been deeply studied in pay- 
Table 2. Basic specification

\begin{tabular}{|c|c|c|c|c|c|c|}
\hline & $\begin{array}{l}(1) \\
\mathrm{EU}\end{array}$ & $\begin{array}{l}(2) \\
\mathrm{EU}\end{array}$ & $\begin{array}{c}(3) \\
\text { EMU }\end{array}$ & $\begin{array}{c}(4) \\
\text { EMU }\end{array}$ & $\begin{array}{l}(5) \\
\mathrm{EU}\end{array}$ & $\begin{array}{l}(6) \\
E U\end{array}$ \\
\hline Atm & $\begin{array}{c}-0.6992^{* * *} \\
{[0.0784]}\end{array}$ & & $\begin{array}{c}-06673^{* * *} \\
{[0.0820]}\end{array}$ & & $\begin{array}{c}-0.6759^{* * *} \\
{[0.0812]}\end{array}$ & \\
\hline Eftpos & & $\begin{array}{c}-0.6549^{* * *} \\
{[0.0588]}\end{array}$ & & $\begin{array}{c}-0.6873^{* * *} \\
{[0.0553]}\end{array}$ & & $\begin{array}{c}-0.6919^{* * *} \\
{[0.0675]}\end{array}$ \\
\hline Interest rate & $\begin{array}{c}0.5173^{* * *} \\
{[0.0808]}\end{array}$ & $\begin{array}{c}0.3476^{* * *} \\
{[0.0785]}\end{array}$ & $\begin{array}{c}0.5581^{* * *} \\
{[0.0823]}\end{array}$ & $\begin{array}{c}0.3119^{* * *} \\
{[0.0744]}\end{array}$ & & \\
\hline Long term & & & & & $0.7398^{\star * *}$ & $0.3764^{* * *}$ \\
\hline Interest rate & & & & & {$[0.1086]$} & {$[0.1143]$} \\
\hline GDP & $\begin{array}{c}-0.9937^{* * *} \\
{[0.2032]}\end{array}$ & $\begin{array}{c}-0.6405^{\star * *} \\
{[0.1992]}\end{array}$ & $\begin{array}{c}-1.1236^{* * *} \\
{[0.2046]}\end{array}$ & $\begin{array}{c}-0.7281^{* * *} \\
{[0.1904]}\end{array}$ & & \\
\hline Consumption & & & & & $\begin{array}{c}-0.9009^{* *} \\
{[0.1857]}\end{array}$ & $\begin{array}{c}-0.3809^{* *} \\
{[0.1886]}\end{array}$ \\
\hline Integration & $\begin{array}{c}-0.2613^{* * *} \\
{[0.0849]}\end{array}$ & $\begin{array}{c}-0.2275^{\star * *} \\
{[0.0768]}\end{array}$ & $\begin{array}{c}-0.3581^{* * *} \\
{[0.0884]}\end{array}$ & $\begin{array}{c}-0.2401^{* * *} \\
{[0.0751]}\end{array}$ & $\begin{array}{c}-0.3468^{\star * *} \\
{[0.0802]}\end{array}$ & $\begin{array}{c}-0.3484^{* * *} \\
{[0.0733]}\end{array}$ \\
\hline Constant & $\begin{array}{c}8.6753^{* * *} \\
{[1.9374]}\end{array}$ & $\begin{array}{c}5.2224^{* * *} \\
{[1.8825]}\end{array}$ & $\begin{array}{c}10.5457^{\star * *} \\
{[1.9181]}\end{array}$ & $\begin{array}{c}6.0200^{* * *} \\
{[1.7929]}\end{array}$ & $\begin{array}{c}6.4645^{\star * *} \\
{[1.5864]}\end{array}$ & $\begin{array}{c}2.3809 \\
{[1.5980]}\end{array}$ \\
\hline Observations & 168 & 168 & 168 & 168 & 168 & 168 \\
\hline $\mathrm{R} 2$ & 0.66 & 0.65 & 0.64 & 0.67 & 0.68 & 0.67 \\
\hline Hausman test & 7.19 & $13.99^{* * *}$ & 7.79 & $13.59^{* * *}$ & 4.48 & 7.67 \\
\hline
\end{tabular}

Note: ${ }^{* *},{ }^{* *},{ }^{*}$ statistically significant at $0.01,0.05$ and 0.1 respectively.

ment literature. Negative EFTPOS coefficient confirms previous evidence that developed and widespread point of sale terminal networks reduce cash demand and use.

Previous results on ATM, however, are more inconclusive. Some studies report a positive effect (Stix 2004) whereas others present a negative effect of ATM on cash use. Our results are in line with the latter (see for example Boeschoten (1992), for the Netherlands and Snellman et al. (2001), for several European countries). They come closer to Rinaldi (2001) who finds that the presence of ATM together with EFTPOS has a negative effect on outstanding money. These negative effects could be explained by the fact that greater access to more technologically developed payment facilities makes people withdraw just the amount of cash needed for small transactions in the near future, without the need to keep big amounts of money in their wallet. This evidence on CEECs also agrees with Humphrey et al. (2001) who do not find evidence of a substitution effect between ATM and EFTPOS. Similarly, Markose and Loke (2003) argue that money demand functions begin to break down in the late 1970s as a consequence of the introduction of new technologies, such as EFTPOS and ATM. Further, our evidence adds to the discussion on the use of alternative means of payment: it does not only depends on a country's own technological development but also on technology advances originated in the accepting countries, as claimed by the theoretical model. 
The other relevant variable according to the model, the nominal interest rate, presents a positive and significant coefficient. In the short term agent's reaction to a change in monetary policy should be to use less electronic payments and more cash when interest rate decreases. However, the behavior of interest rates in our sample is governed by the monetary policy convergence, which is part of the Treaty criterion to access the European Union. Initially the interest rates in CEECs displayed much higher values than the EU reference rates (ECB 2004, 2006). Thus decreasing interest rates coincide with decreasing cash to cards ratio. We think that this convergence effect overcomes the usual negative relationship between interest rates and cash use. This result maintains when long-term interest rate is introduced in the estimation instead.

Economic development, measured as per worker GDP (or consumption), has a negative and significant coefficient, meaning that more developed countries present lower cash use. This result confirms previous empirical evidence on international comparisons (Callado, Utrero 2004, 2007) and persists when a different proxy (consumption) is introduced (columns 5 and 6).

As a measure of the institutional environment and evolution during the integration period, we introduce the integration variable. The estimated coefficient is negative and significant in all runs. Therefore, the prospect of becoming an EU member has a positive effect on card use. It can be considered as a positive shock for the reliability of the economic and financial systems. It also confirms that the transformation of payment decisions started before entering the EU in 2004, as claimed in ECB reports (ECB 1999). Therefore, economic development, payment technology, institutional environment and its evolution matter in payment decisions.

\subsection{Robustness analysis}

We have already shown that results are invariant to alternative variable definitions and a different benchmark group. Here we present additional evidence to examine their robustness controlling that results are not driven by omitted variables. Previous empirical papers have shown that, even with the globalization of card use, differences among countries could persist due to different demographic and cultural factors (Humphrey et al. 1996). Therefore, the positive effect of the integration process in the modernization of payment methods could be associated to demographic or cultural changes. To discard omitted effects, we introduce different controls on demographic and cultural habits. For this purpose we use Population and Social Condition statistics developed by EUROSTAT. In particular we control for age, education, urban population, degree of innovation and crime. Table A.2 in Appendix 2 collects summary statistics.

Wasberg et al. (1992) show a negative relationship between card use and age. To proxy for age, we introduce the percentage of school-age population (up to tertiary education). We expect a positive relationship, the younger you are the more cash you use. Carner and Luckett (1992) show a positive relationship between education and card use since a low level of literacy and education may also be factors impinging on card use. As a measure of education and literacy, we introduce the percentage of college enrolments and the books 
published scaled by population. Kaynak and Harcar (2001) claim that card usage is more prevalent among urban and semi-urban areas. Traditional consumers who reside in rural areas may still prefer cash transactions. Accordingly, we use the percentage of urban population. Humphrey (2010) claims that more innovative societies are more willing to use new technologies, and therefore, new methods of payments will diffuse more rapidly. Innovation in society is introduced by gross expenditure on research and development to GDP. Humphrey et al. (1996) find that the use of non-cash payment methods is related to the prevalence of violent crime within countries. In consequence, we control for the level of criminality (total number of violent crimes by population). Results are shown in Table 3 . Looking at the variables of interest, it can be observed that the signs and the significance are unaltered throughout alternative specifications, meaning that the results of our analysis are robust. Reviewing the control variables introduced, the coefficients are not significant. This suggests that when the institutional evolution is considered together with the technology development, demographic and cultural aspects are much less important in payment methods decisions.

An additional issue in this context is the simultaneous relationship between cash and ATM (Snellman, Virén 2009). To control for this potential bias, we use Generalized Method of Moments (GMM) estimation. Although simultaneity between cash and ATM can also be controlled by using a simultaneous equation estimator (e.g., maximum likelihood and twoor three-stage least squares) our choice is based on consistency concerns. In other words, the above mentioned estimators are more efficient than GMM, but they are not consistent since they do not eliminate unobservable heterogeneity. In contrast, GMM estimation implies less efficiency, but it is consistent because it eliminates unobservable heterogeneity. Traditionally GMM uses first-difference transformation. However, this technique has a weakness. It magnifies gaps in unbalanced panels (Roodman 2009). Arellano and Bover (1995) propose a second transformation "orthogonal deviations" that minimizes data loss and since lagged observations do not enter the formula, they are valid as instruments ${ }^{13}$. Since the sample is small, we decide to use this transformation in order to preserve sample size. Further, to avoid over-fitting, we collapse the instrument matrix ${ }^{14}$. Table 4 collects the results.

Focusing first on the diagnostic tests, Hansen's J-statistics for all specifications are too small to reject the null hypothesis that the instruments are valid. Therefore the excluded instruments are correctly omitted from the estimated equation. Further, $\operatorname{AR}(1)$ and $\operatorname{AR}(2)$ test statistics for the first and second order serial correlation in the first-differenced residuals indicate, as required, that while we can sometimes have evidence of first order autocorrelation, we always accept the null hypothesis of no second order autocorrelation. Looking at the variables of interest, the results are very similar to those presented in Table 2.

\footnotetext{
${ }^{13}$ In the estimation, lagged values of cash, interest rate, GDP per worker and banking structure are introduced in GMM-style, while ATM and EFTPOS receive the standard treatment for endogenous variables. Further, time dummies are included as IV-style instruments.

${ }^{14}$ We have chosen not to run two-step GMM due to well-known finite sample problems associated with the standard errors of two-step estimates. Indeed, two-step estimates of the model (not reported) suggest significant downward bias in the standard errors, even after using the Windmeijer (2005) correction.
} 


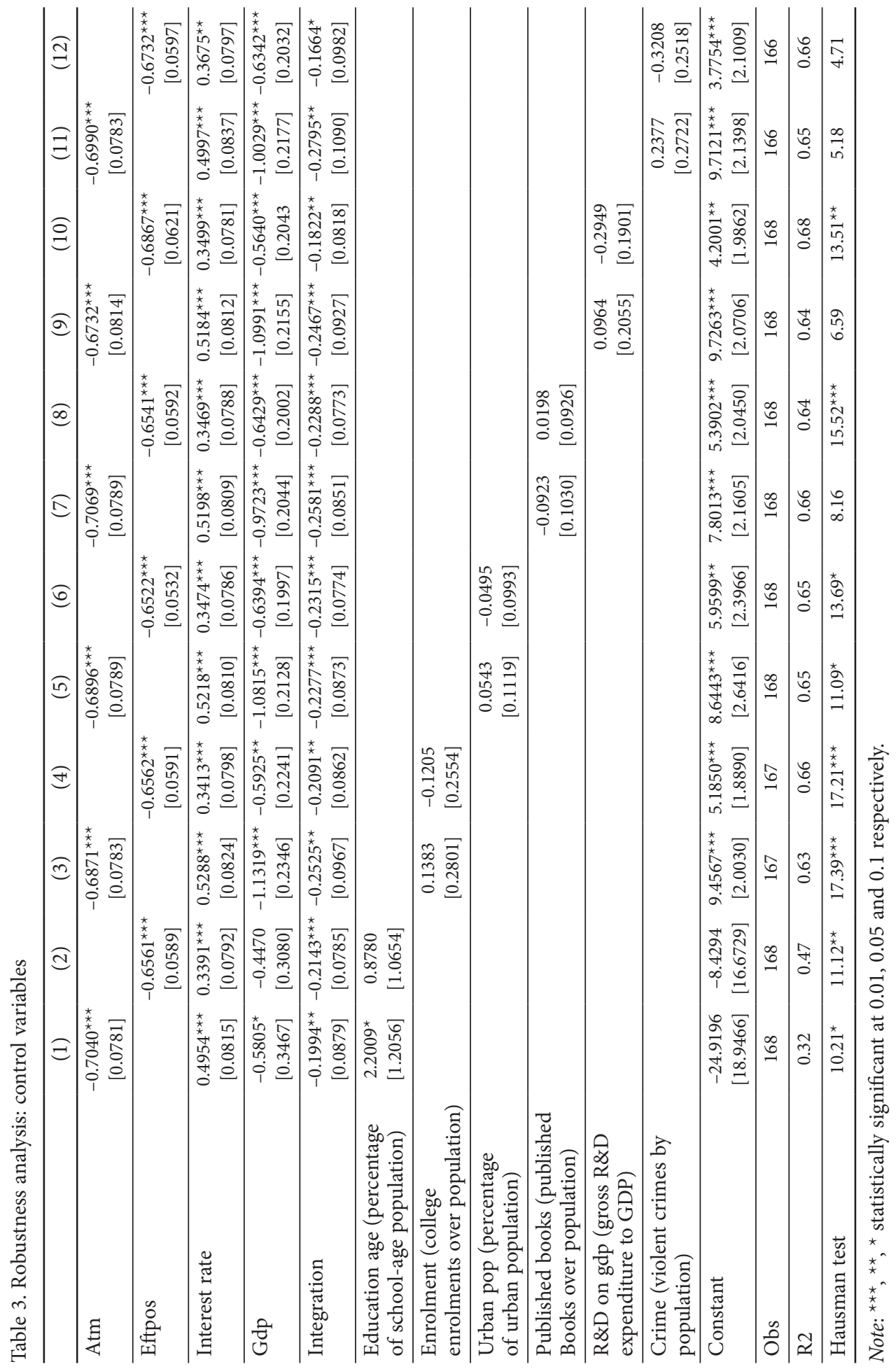


Table 4. Robustness analysis: GMM analysis

\begin{tabular}{lcc}
\hline & $(1)$ & $(2)$ \\
\hline Atm & $-1.2614^{* * *}$ & \\
\hline Eftpos & & \\
& & $-1.1790]$ \\
{$[0.1036]$} \\
\hline Interest rate & $0.3819^{* *}$ & 0.1324 \\
& {$[0.1666]$} & {$[0.1228]$} \\
\hline Gdp & 0.1050 & 0.6726 \\
& {$[0.4804]$} & {$[0.6809]$} \\
\hline Integration & $-0.4384^{*}$ & $-0.4782^{*}$ \\
& {$[0.2517]$} & {$[0.2821]$} \\
\hline Constant & -1.8661 & -7.0521 \\
& {$[4.2619]$} & {$[5.9148]$} \\
\hline Observations & 168 & 168 \\
\hline AR(1) & 0.20 & -0.36 \\
\hline AR(2) & 0.26 & -0.31 \\
\hline Hansen tests & 6.83 & 9.82 \\
Overidentification & -0.00 & 0.00 \\
\hline Exogeneity &
\end{tabular}

Note: ${ }^{\star * *},{ }^{* *},{ }^{\star}$ significant at $.01, .05$ and .1 respectively.

ATM and EFTPOS affect negatively and significantly the cash use. The institutional variable maintains the sign of the coefficients and although the significance level is a bit lower, it is still significant. Therefore, institutional variables and payment technology impact payment decisions, as suggested by the model, and these results are robust to endogeneity.

From the time series analysis point of view some problems may arise in the results found because a part of the data may be non-stationary. As a consequence, that would give rise to co-integration analysis and specification of an error-correction model. We perform a battery of panel unit root tests. Table 5 collects the results. Individual unit root process is rejected for card to cash, ATM, EFTPOS and GDP. For interest rates results are inconclusive and depend on the test performed. Therefore, we do not find evidence of non-stationarity in our sample.

\section{Conclusions}

We present a general equilibrium model on payment choice at retail level that allows us to analyze the evolution of consumers' payments when a country enters an economic and monetary union. The model shows that the relative importance of cash to electronic payments will diminish with technology development. In the case of a country accessing an economic union, the effect will be based both on its own technology level and also on the one of the accepting group. After the accession, the less developed economy gradually adapts to the payment technology of the accepting countries reducing the gap between consumers' choices among both parties. 
Table 5. Panel data unit root tests

a. Cash over card use

\begin{tabular}{lcccc}
\hline \multicolumn{1}{c}{ Method } & Statistic & P-value & Cross-sections & Obs \\
\hline & Null: Unit Root (assumes common unit root process) & \\
\hline Levin, Lin \& Chu & -3.8228 & 0.0001 & 11 & 132 \\
\hline Breitung & \multicolumn{5}{l}{} \\
\hline \multicolumn{5}{l}{ Null: Unit Root (assumes individual unit root process) } \\
\hline Im, Pesaran and Shin & -6.1142 & 0.0000 & 12 & 154 \\
\hline ADF-Fisher Chi-Sqr & 53.5760 & 0.0005 & 12 & 144 \\
\hline ADF-Choi test & -1.8686 & 0.0308 & 12 & 144 \\
\hline PP-Fisher Chi-Sqr & 123.395 & 0.000 & 12 & 156 \\
\hline PP-Choi test & -7.3738 & 0.000 & 12 & 156 \\
\hline
\end{tabular}

b. ATM

\begin{tabular}{lcccc}
\hline \multicolumn{1}{c}{ Method } & Statistic & P-value & Cross-sections & Obs \\
\hline & Null: Unit Root (assumes common unit root process) & \\
\hline Levin, Lin \& Chu & -10.4013 & 0.000 & 8 & 103 \\
\hline Breitung & 0.6387 & 0.7369 & 12 & 154 \\
\hline \multicolumn{4}{l}{ Null: Unit Root (assumes individual unit root process) } & \\
\hline AD, Pesaran and Shin & -6.7945 & 0.000 & 12 & 154 \\
\hline ADF-Choi Z test & 92.6257 & 0.000 & 12 & 154 \\
\hline PP-Fisher Chi-Sqr & -3.9890 & 0.000 & 12 & 154 \\
\hline PP-Choi test & 105.95 & 0.000 & 12 & 156 \\
\hline
\end{tabular}

\section{c. EFTPOS}

\begin{tabular}{lcccc}
\hline \multicolumn{1}{c}{ Method } & Statistic & P-value & Cross-sections & Obs \\
\hline & Null: Unit Root (assumes common unit root process) & \\
\hline Levin, Lin \& Chu & -1.6607 & 0.048 & 8 & 103 \\
\hline Breitung & -3.2367 & 0.0006 & 12 & 135 \\
\hline \multicolumn{4}{l}{ Null: Unit Root (assumes individual unit root process) } \\
\hline Im, Pesaran and Shin & -8.5380 & 0.000 & 12 & 144 \\
\hline ADF-Fisher Chi-Sqr & 107.134 & 0.000 & 12 & 144 \\
\hline PDF-Choi test & -7.3430 & 0.000 & 12 & 144 \\
\hline PP-Choi test & 95.6011 & 0.000 & 12 & 156 \\
\hline
\end{tabular}


d. Interest rate

\begin{tabular}{lcccc}
\hline \multicolumn{1}{c}{ Method } & Statistic & P-value & Cross-sections & Obs \\
\hline & Null: Unit Root (assumes common unit root process) & \\
\hline Levin, Lin \& Chu & -4.5956 & 0.000 & 12 & 144 \\
\hline Breitung & 2.2510 & 0.9878 & 11 & 132 \\
\hline & Null: Unit Root (assumes individual unit root process) & 12 & 144 \\
\hline Im, Pesaran and Shin & -0.3172 & 0.3755 & 12 & 144 \\
\hline ADF-Fisher Chi-Sqr & 36.3442 & 0.0508 & 12 & 144 \\
\hline ADF-Choi test & $0-2.3712$ & 0.0089 & 11 & 143 \\
\hline PP-Fisher Chi-Sqr & 27.8613 & 0.1803 & 12 & 156 \\
\hline PP-Choi test & 2.2321 & 0.9872 & & 12 \\
\hline
\end{tabular}

e. GDP

\begin{tabular}{lcccc}
\hline \multicolumn{1}{c}{ Method } & Statistic & P-value & Cross-sections & Obs \\
\hline & Null: Unit Root (assumes common unit root process) & \\
\hline Levin, Lin \& Chu & -3.0398 & 0.0012 & 12 & 144 \\
\hline Breitung & 2.2873 & 0.9889 & 12 & 132 \\
\hline & Null: Unit Root (assumes individual unit root process) & 12 & 150 \\
\hline Im, Pesaran and Shin & -2.6424 & 0.0041 & 12 & 144 \\
\hline ADF-Fisher Chi-Sqr & 44.1657 & 0.0073 & 12 & 144 \\
\hline ADF-Choi test & -2.9020 & 0.0019 & 11 & 143 \\
\hline PP-Fisher Chi-Sqr & 60.9794 & 0.0000 & 12 & 156 \\
\hline PP-Choi test & -3.8002 & 0.0001 & & \\
\hline
\end{tabular}

The implications of the model are tested in the context of the EU enlargement process. This extension of the EU provides data on a natural (real) experiment where the conclusions of the model can be examined. Results from the econometric analysis are in line with the theoretical model. First, technology is the main factor driving the consumers' payment choice. In particular, technology development relative to the accepting countries indicates that the closer the accessing payment technology to the accepting one, the lesser the relative use of cash. Second, when controlling for endogeneity, the interest rate is less relevant in explaining the ratio of cash to electronic payments. This fact clearly reinforces the role of technology in the analysis. Third, the integration variable that accounts for the institutional evolution is significant, even when endogeneity issue is considered. The institutional transformation undergone to become EU member is considered a positive shock for the reliability of the economic and payment methods and therefore, affects payment instrument choice. Our results are robust to different estimation techniques, alternative variable definitions, different accepting groups, the introduction of additional controls and non-stationarity issues. 
The present study provides additional evidence on consumers' payment instrument choice. The findings suggest that payment instrument use can be influenced by the intensive adaptation of countries' payment technology to relatively higher standards. Current results confirm the relevance of the new institutional environment and structural transformation called for by the integration into an economic union.

\section{Acknowledgements}

We would like to thank the editor and anonymous referees for helpful comments on earlier versions of the paper. We are also grateful to participants of SAEe 2011 meeting for comments. Financial support from the Spanish Ministry of Science (projects ECO201345395-R, ECO2010-16353, ECO2012-37572 and ECO2013-48496-C4-4-R), the Regional Government of Aragón and FSE (project S125: Compete Research Group) and Generalitat de Catalunya (grant SGR 2009-0600) is also gratefully acknowledged.

\section{References}

Andrieş, A. M.; Capraru, B. 2012. Competition and efficiency in EU27 banking systems, Baltic Journal of Economics 12: 41-60. http://dx.doi.org/10.1080/1406099X.2012.10840510

Anguelov, C. E.; Hilgert, M. A.; Hogarth, J. M. 2004. US consumers and electronic banking, 1995-2003, Federal Reserve Bulletin 90: 1-18.

Arellano, M.; Bover, O. 1990. La Econometría de Datos de Panel, Investigaciones Económicas 14: 3-45.

Arellano, M.; Bover, O. 1995. Another look at the instrumental variable estimation of error-components models, Journal of Econometrics 68: 29-51. http://dx.doi.org/10.1016/0304-4076(94)01642-D

Barro, R. J.; Sala-i-Martin, X. 1995. Economic growth. McGraw-Hill.

BIS. 2005. Central bank oversight of payment and settlement systems. Committee on Payment and Settlement Systems.

Boeschoten, W. C. 1992. Currency use and payment patterns. Kluwer Academic Publishers. http://dx.doi.org/10.1007/978-94-011-2518-5

Callado, F.; Utrero, N. 2004. European payment systems and Monetary Union, Journal of Financial Transformation 12: 85-92.

Callado, F.; Utrero, N. 2007. Towards economic and Monetary Union: changing trends in payment systems for new European members, Journal of Financial Transformation 20: 168-174.

Carner, G. B.; Luckett, C. A. 1992. Development in the pricing of credit services, Federal Review Bulletin 78: 652-666.

Caviglia, G.; Krause, G.; Thimann, C. 2002. Key features of the financial sectors in EU accession countries, in Financial Sectors in the Accession Countries. European Central Bank.

Dabrowski, M.; Radziwill, A. 2007. Regional vs. global public goods: the case of post-communist transition, Studies and Analyses CASE 336.

Drehmann, M.; Goodhart, C.; Krueger, M. 2002. Challenges to currency. Will cash resist the e-money challenge?, Economic Policy 17: 193-228. http://dx.doi.org/10.1111/1468-0327.00087

ECB. 1999. Blue book, payment systems in countries that have applied for membership of the European Union. European Central Bank. 
ECB. 2002. The Eurosystem's dialogue with EU accession countries. European Central Bank.

ECB. 2004. Convergence report. European Central Bank.

ECB. 2006. Convergence report. European Central Bank.

ECB. 2010. $7^{\text {th }}$ SEPA progress report. European Central Bank.

ECB [online]. 2013. Statistics website. European Central Bank [cited December 2013]. Available from Internet: https://www.ecb.europa.eu/stats/html/index.en.html

English, W. B. 1999. Inflation and financial sector size, Journal of Monetary Economics 44: 379-400. http://dx.doi.org/10.1016/S0304-3932(99)00033-1

Eurostat [online] 2013. Database website [cited December 2013]. Available from Internet: http:// ec.europa.eu/eurostat/data/database

Evans, D. S.; Schmalensee, R. 2009. Innovation and evolution of the payments industry, in R. E. Litan, M. N. Baily. Moving money: the future of consumer payments, Chapter 3. Brookings eds., 36-77.

Ferrari, S.; Verboven, F.; Degryse, H. 2010. Investment and usage of new technologies: evidence from a shared ATM network, American Economic Review 100: 1046-1079. http://dx.doi.org/10.1257/aer.100.3.1046

Gillman, M. 1993. The welfare cost of inflation in a cash-in-advance economy with costly credit, Journal of Monetary Economics 31: 97-115. http://dx.doi.org/10.1016/0304-3932(93)90018-B

Hasan, I.; De Renzis, T.; Schmiedel, H. 2013. Retail payments and the real economy, Working Paper Series. 1572. European Central Bank.

Hasan, I.; Schmiedel, H.; Song, L. I. 2012. Returns to retail banking and payment, Journal of Financial Services and Research 41: 163-195. http://dx.doi.org/10.1007/s10693-011-0114-y

Hayashi, F.; Klee, E. 2003. Technology adoption and consumer payments: evidence from survey data, Review of Network Economics 2: 175-190. http://dx.doi.org/10.2202/1446-9022.1025

Hildebrandt, A. 2002. What is so special about enlarging EU towards the East? A comparison with Southern enlargement, Working Paper 13/2002. Bank of Finland.

Hromcová, J. 2008. Learning-or-doing in a cash-in-advance economy with costly credit, Journal of Economic Dynamics and Control 32: 2826-2853. http://dx.doi.org/10.1016/j.jedc.2007.11.001

Humphrey, D. B. 2004. Replacement of cash by cards in U.S. consumer payments, Journal of Economics and Business 56: 211-225. http://dx.doi.org/10.1016/j.jeconbus.2003.09.001

Humphrey, D. B. 2010. Retail payments: new contributions, empirical results and unanswered questions, Journal of Banking and Finance 34: 1729-1737. http://dx.doi.org/10.1016/j.jbankfin.2010.04.008

Humphrey, D. B.; Kim, M.; Vale, B. 2001. Realizing the gains from electronic payments: costs, pricing, and payment choice, Journal of Money, Credit, and Banking 33: 216-234.

http://dx.doi.org/10.2307/2673882

Humphrey, D. B.; Pulley, L. B.; Vesala, J. M. 1996. Cash, paper, and electronic payments: a cross-country analysis, Journal of Money, Credit, and Banking 28: 914-939. http://dx.doi.org/10.2307/2077928

Humphrey, D. B.; Willesson, M.; Bergendahl, G.; Lindblom, T. 2006. Benefits from a changing payment technology in European banking, Journal of Banking and Finance 30: 1631-1652.

http://dx.doi.org/10.1016/j.jbankfin.2005.09.009

Ireland, P. N. 1994a. Money and growth: an alternative approach, American Economic Review 84: 47-65.

Ireland, P. N. 1994b. Economic growth, financial evolution, and the long-run behavior of velocity, Journal of Economic Dynamics and Control 18: 815-848. http://dx.doi.org/10.1016/0165-1889(94)90033-7

Kaynak, E.; Harcar, T. 2001. Consumers attitudes and intentions towards credit card usage in an advanced developing country, Journal of Financial Services Marketing 6: 24-39.

http://dx.doi.org/10.1057/palgrave.fsm.4770038 
La Porta, R.; Lopez-de-Silanes, F.; Shleifer, A.; Vishny, R. W. 1997. Legal determinants of external finance, Journal of Finance 52: 1131-1150. http://dx.doi.org/10.1111/j.1540-6261.1997.tb02727.x

Litan, R. E.; Baily, M. N. 2009. Moving money: the future of consumer payments, in R. E. Litan, M. N. Baily. Moving money: the future of consumer payments, Chapter 1. Brookings eds., 1-18.

Lucas, R. E. Jr. 2009. Trade and the diffusion of the industrial revolution, American Economic Journal: Macroeconomics 1: 1-25. American Economic Association. http://dx.doi.org/10.1257/mac.1.1.1

Lucas, R. E. Jr.; Stokey, N. L. 1983. Optimal fiscal and monetary policy in an economy without capital, Journal of Monetary Economics 12: 55-93. http://dx.doi.org/10.1016/0304-3932(83)90049-1

Markose, S. M.; Loke, Y. J. 2003. Network effects on cash-card substitution in transactions and low interest rate regimes, The Economic Journal 113: 456-476. http://dx.doi.org/10.1111/1468-0297.00124

Marquis, M. H.; Reffett, K. L. 1994. New technology spillovers into the payment system, The Economic Journal 104: 1123-1138. http://dx.doi.org/10.2307/2235068

Rinaldi, L. 2001. Payment cards and money demand in Belgium. Discussions Paper Series 01.16. Katholieke Universiteit Leuven, Center for Economic Studies.

Roodman, D. 2009. How to do xtabond2: an introduction to "difference" and "system" GMM in stata, The Stata Journal 9: 86-136.

Snellman, H.; Virén, M. 2009. ATM networks and cash usage, Applied Financial Economics 19(10-12): 841-851. http://dx.doi.org/10.1080/09603100701675548

Snellman H.; Vesala, J.; Humphrey, D. B. 2001. Substitution of noncash payments instruments for cash in Europe, Journal of Financial Services Research 19: 131-145. http://dx.doi.org/10.1023/A:1011151219545

Stirbu, C. 2004. Financial market integration in a wider European Union, HWWA Discussion Paper 26331. Hamburg Institute of International Economics.

Stix, H. 2004. How do debit cards affect cash demand? Survey data evidence, Empirica 31: 93-115. http://dx.doi.org/10.1007/s10663-004-1079-y

Tang, H.; Zoli, E.; Klytchnikova, I. 2000. Banking crises in transition countries: fiscal costs and related issues, World Bank Policy research working paper 2484.

Thimann, C. 2002. Summary "Financial sectors in EU accession countries: issues for the workshop and summary of the discussion", in Financial Sectors in the Accession Countries, European Central Bank.

Wasberg, C.; Hira, T. K.; Fanslow, A. M. 1992. Credit card usage and consumer debt of households, Journal of Consumer Studies and Home Economics 16: 19-32. http://dx.doi.org/10.1111/j.1470-6431.1992.tb00496.x

Windmeijer, F. 2005. A finite sample correction for the variance of linear efficient two-step GMM estimators, Journal of Econometrics 126: 25-51. http://dx.doi.org/10.1016/j.jeconom.2004.02.005

Yang, B.; Ching, A. 2013. Dynamics of consumer adoption of financial innovations: the case of ATM cards, Management Science 60(4): 903-922. http://dx.doi.org/10.1287/mnsc.2013.1792 


\section{APPENDIX}

\section{Appendix 1. Asymptotic balanced growth path behavior}

The economy can reach the balanced growth path asymptotically, as $t \rightarrow \infty$, when all stationary variables remain constant and all non-stationary variables grow at a constant rate. That means that the existence of the balanced growth path requires $\lim _{t \rightarrow \infty} R_{t}=\lim _{t \rightarrow \infty} R_{t+1}=R$. Recall that we assumed in section 2.1.2. that $\lim _{t \rightarrow \infty} \gamma^{\text {technolog } y}\left(k_{t}\right)=0$. Then, the cutoff index will approach unity, $\lim _{t \rightarrow \infty} s\left(k_{t}, R\right)=1$, see equation (24). We can rewrite equations (16) and (17) for the CES utility function given in the equation (22) as

$$
\begin{aligned}
& \frac{1}{c_{t}^{0}(j)}=\left(R_{t} \lambda_{t}\right)^{\frac{1}{\theta}} ; \\
& \frac{1}{c_{t}^{1}(j)}=\left(\lambda_{t}\right)^{\frac{1}{\theta}} .
\end{aligned}
$$

Using (A2), (12), (21) and (24) we can obtain the long run growth rate of electronic consumption:

$$
\lim _{t \rightarrow \infty} \frac{e_{t+1}}{e_{t}}=\lim _{t \rightarrow \infty} \frac{s\left(R_{t+1}, k_{t+1}\right) c^{1}\left(\lambda_{t+1}\right)}{s\left(R_{t}, k_{t}\right) c^{1}\left(\lambda_{t}\right)}=\left(\frac{\lambda_{t}}{\lambda_{t+1}}\right)^{\frac{1}{\theta}}=(\beta A)^{\frac{1}{\theta}}
$$

The long run growth rate of cash consumption and payment to intermediary will depend on the specification of $\gamma^{t e c h n o l o g} y\left(k_{t}\right)$, but in general it will be lower than the growth rate of electronic consumption. For example, if we set $\gamma^{\text {technolog } y}\left(k_{t}\right)=\frac{1}{k_{t}^{\omega}}$, where $0<\omega \leq 1$, we can obtain following
for the growth rate of cash consumption:

$$
\lim _{t \rightarrow \infty} \frac{m_{t+1}}{m_{t}}=\lim _{t \rightarrow \infty} \frac{\left[1-s\left(R_{t+1}, k_{t+1}\right)\right] c^{0}\left(\lambda_{t+1}\right)}{\left[1-s\left(R_{t}, k_{t}\right)\right] c^{0}\left(\lambda_{t}\right)}=\left(\frac{k_{t}}{k_{t+1}}\right)^{\omega}\left(\frac{\lambda_{t}}{\lambda_{t+1}}\right)^{\frac{1}{\theta}},
$$

and for the long run growth rate of the payment to the intermediary:

$\lim _{t \rightarrow \infty} \frac{g_{t+1}}{g_{t}}=\lim _{t \rightarrow \infty} \frac{\left\{-s\left(R_{t+1}, k_{t+1}\right)-\ln \left[1-s\left(R_{t+1}, k_{t+1}\right)\right]\right\} \frac{1}{k_{t+1}^{\omega}} c^{1}\left(\lambda_{t+1}\right)}{\left\{-s\left(R_{t}, k_{t}\right)-\ln \left[1-s\left(R_{t}, k_{t}\right)\right]\right\} \frac{1}{k_{t}^{\omega}} c^{1}\left(\lambda_{t}\right)}=\left(\frac{k_{t}}{k_{t+1}}\right)^{\omega}\left(\frac{\lambda_{t}}{\lambda_{t+1}}\right)^{\frac{1}{\theta}}$,

where

$$
g_{t}=\int_{0}^{s\left(R_{t}, k_{t}\right)} \gamma_{t}(j) d j .
$$

The goods market equilibrium (19), rewritten using (20), (21) and (A6) as:

$$
A k_{t}=m_{t}+e_{t}+g_{t}+k_{t+1},
$$

implies that when all growth rates remain constant, the electronic consumption must grow like capital. Capital grows at the same rate as output. 


\section{Appendix 2. Individual countries statistics}

Table A.1. Descriptive statistics by country

\begin{tabular}{lcccccc}
\hline & Pccurrency & Pccardop & irate & Pceftpos & Pcatm & Pwgdp \\
\hline Bulgaria & 271.8394 & 0.8161 & 15.4043 & 0.0013 & 0.0003 & 6553.7550 \\
& $(165.8255)$ & $(0.9768)$ & $(33.9884)$ & $(0.0019)$ & $(0.0003)$ & $(2174.07)$ \\
\hline Cyprus & 1027.5870 & 20.6234 & 4.2393 & 0.0164 & 0.0005 & 37230.7800 \\
& $(255.5085)$ & $(12.3847)$ & $(1.4311)$ & $(0.0081)$ & $(0.0002)$ & $(5105.155)$ \\
\hline Czech Rep & 690.1950 & 5.3874 & 5.8093 & 0.0030 & 0.0002 & 18018.7700 \\
& $(339.7713)$ & $(5.4033)$ & $(5.3341)$ & $(0.0023)$ & $(0.0001)$ & $(7070.125)$ \\
\hline Estonia & 340.5366 & 44.0839 & 3.1450 & 0.0077 & 0.0005 & 14877.3900 \\
& $(101.8856)$ & $(43.4747)$ & $(1.2424)$ & $(0.0063)$ & $(0.0002)$ & $(6570.648)$ \\
\hline Hungary & 505.1942 & 7.1462 & 11.8279 & 0.0032 & 0.0003 & 18231.2300 \\
& $(208.7554)$ & $(6.1967)$ & $(5.4665)$ & $(0.002)$ & $(0.0001)$ & $(6313.556)$ \\
\hline Latvia & 382.1116 & 15.1308 & 4.8107 & 0.0048 & 0.0003 & 11415.8500 \\
& $(140.0498)$ & $(16.833)$ & $(2.5643)$ & $(0.0036)$ & $(0.0002)$ & $(5591.857)$ \\
\hline Lithuania & 385.1401 & 10.0679 & 4.1807 & 0.0047 & 0.0002 & 12198.0600 \\
& $(219.1643)$ & $(10.6205)$ & $(2.126)$ & $(0.0049)$ & $(0.0002)$ & $(5260.788)$ \\
\hline Malta & 2634.6310 & 11.8753 & 3.9057 & 0.0158 & 0.0004 & 30218.9900 \\
& $(328.6598)$ & $(8.6201)$ & $(1.1995)$ & $(0.0055)$ & $(0.0001)$ & $(3720.698)$ \\
\hline Poland & 339.0553 & 5.6949 & 11.2257 & 0.0027 & 0.0002 & 15057.3500 \\
& $(150.2792)$ & $(6.0405)$ & $(7.3449)$ & $(0.0022)$ & $(0.0001)$ & $(5115.656)$ \\
\hline Romania & 121.0684 & 1.0480 & 32.4464 & 0.0013 & 0.0002 & 7242.7990 \\
& $(97.5587)$ & $(1.4558)$ & $(25.8324)$ & $(0.0019)$ & $(0.0002)$ & $(4679.778)$ \\
\hline Slovakia & 389.5224 & 5.8367 & 7.5986 & 0.0026 & 0.0003 & 14849.4100 \\
& $(136.2764)$ & $(6.37)$ & $(5.4226)$ & $(0.0019)$ & $(0.0001)$ & $(6782.954)$ \\
\hline Slovenia & 322.8070 & 38.9769 & 4.2186 & 0.0131 & 0.0006 & 27211.8800 \\
& $(69.6651)$ & $(15.0209)$ & $(1.2055)$ & $(0.006)$ & $(0.0002)$ & $(6725.561)$ \\
\hline
\end{tabular}

Table A.2. Summary statistics of control variables

\begin{tabular}{lcccccc}
\hline & $\begin{array}{c}\text { School-age } \\
\text { pop (\%) }\end{array}$ & $\begin{array}{c}\text { Enrolment } \\
\text { (per capita) }\end{array}$ & $\begin{array}{c}\text { Urban pop } \\
(\%)\end{array}$ & $\begin{array}{c}\text { Published books } \\
\text { (per capita) }\end{array}$ & $\begin{array}{c}\text { Gross R\&D } \\
\text { to gdp }\end{array}$ & $\begin{array}{c}\text { Violent crimes } \\
\text { (per capita) }\end{array}$ \\
\hline Bulgaria & 0.1356 & 45.7609 & 69.3786 & 0.0006 & 0.5049 & 0.0190 \\
& $(0.0092)$ & $(3.9431)$ & $(1.2461)$ & $(0.0001)$ & $(0.0302)$ & $(0.0027)$ \\
\hline Cyprus & 0.1795 & 30.3208 & 67.0064 & 0.0013 & 0.3279 & 0.0081 \\
& $(0.0178)$ & $(9.3536)$ & $(1.1366)$ & $(0.0002)$ & $(0.1065)$ & $(0.0019)$ \\
\hline Czech & 0.1573502 & 38.22558 & 74.08329 & 0.001125 & 1.271492 & 0.0362795 \\
Republic & $(0.0167)$ & $(14.382)$ & $(0.406)$ & $(0.0001)$ & $(0.1759)$ & $(0.0029)$ \\
\hline Estonia & 0.163543 & 57.11042 & 70.16872 & 0.00227 & 0.8351777 & 0.0369066 \\
& $(0.0183)$ & $(10.3995)$ & $(1.4197)$ & $(0.0002)$ & $(0.3281)$ & $(0.005)$ \\
\hline Hungary & 0.1470 & 48.1188 & 65.1351 & 0.0010 & 0.8560 & 0.0451 \\
& $(0.0105)$ & $(16.021)$ & $(1.8956)$ & $(0.0001)$ & $(0.1251)$ & $(0.005)$ \\
\hline Latvia & 0.1642 & 61.0283 & 68.0786 & 0.0009 & 0.4820 & 0.0214 \\
& $(0.0185)$ & $(14.3698)$ & $(0.294)$ & $(0.0001)$ & $(0.1118)$ & $(0.0041)$ \\
\hline Lithuania & 0.1729 & 59.1920 & 67.0309 & 0.0012 & 0.6706 & 0.0217 \\
& $(0.0111)$ & $(19.3699)$ & $(0.3588)$ & $(0.0001)$ & $(0.1151)$ & $(0.0017)$ \\
\hline
\end{tabular}


End of Table A.2

\begin{tabular}{lcccccc}
\hline & $\begin{array}{c}\text { School-age } \\
\text { pop (\%) }\end{array}$ & $\begin{array}{c}\text { Enrolment } \\
\text { (per capita) }\end{array}$ & $\begin{array}{c}\text { Urban pop } \\
(\%)\end{array}$ & $\begin{array}{c}\text { Published books } \\
\text { (per capita) }\end{array}$ & $\begin{array}{c}\text { Gross R\&D } \\
\text { to gdp }\end{array}$ & $\begin{array}{c}\text { Violent crimes } \\
\text { (per capita) }\end{array}$ \\
\hline Malta & 0.1779 & 25.7930 & 97.2756 & 0.0008 & 0.3918 & 0.0414 \\
& $(0.0155)$ & $(7.1028)$ & $(8.7483)$ & $(0.0002)$ & $(0.1594)$ & $(0.0037)$ \\
\hline Poland & 0.1760 & 55.1306 & 64.2517 & 0.0025 & 0.6093 & 0.0321 \\
& $(0.0218)$ & $(13.2785)$ & $(9.7713)$ & $(0.0076)$ & $(0.0501)$ & $(0.0048)$ \\
\hline Romania & 0.1648 & 37.3723 & 55.1146 & 0.0003 & 0.4813 & 0.0138 \\
& $(0.019)$ & $(17.8688)$ & $(1.7924)$ & $(0.0001)$ & $(0.1137)$ & $(0.0024)$ \\
\hline Slovakia & 0.1882 & 35.4062 & 56.0018 & 0.0006 & 0.6265 & 0.0197 \\
& $(0.0209)$ & $(11.9516)$ & $(0.7246)$ & $(0.0002)$ & $(0.1831)$ & $(0.0024)$ \\
\hline Slovenia & 0.1474 & 67.0758 & 49.3157 & 0.0017 & 1.4517 & 0.0362 \\
& $(0.0132)$ & $(15.8102)$ & $(1.7129)$ & $(0.0003)$ & $(0.1699)$ & $(0.0091)$ \\
\hline
\end{tabular}

Francisco José CALLADO-MUÑOZ. Doctor, Associate Professor at Centro Universitario de la Defensa Zaragoza. Author and co-author of more than 15 scientific articles and 9 book chapters. Reserch interests: Financial economics, Payment Systems, Development, Business Economics and Education economics.

Jana HROMCOVÁ. Doctor, Researcher at Universitat Autònoma de Barcelona, Spain. She is an author and co-author of more than 20 scientific articles and one book chapter. Her research interests are in macroeconomics, monetary economics, payment systems, public economics, labor economics and education.

Natalia UTRERO-GONZÁLEZ. Doctor, Associate Professor at Centro Universitario de la Defensa Zaragoza. Author and co-author of more than 15 scientific articles and 13 book chapters. Research interests: Financial economics, Payment Systems, Development, Business Economics and Education economics. 